\title{
Analysis of Differences in Achieving Cognitive Competency for Clerkship Students of Doctor Profession Study Program Faculty of Medicine Universitas Muslim Indonesia Using Online Learning Methods During the Pandemic Covid 19
}

\author{
Andi Tenri Sanna ${ }^{1}$, Nevi Sulvita Karsa ${ }^{1}$, Marliyanti Akib ${ }^{1}$, Shofiyah Latief ${ }^{1}$, \\ Nasrudin $\mathrm{AM}^{1}$
}

${ }^{1}$ Faculty of Medicine, Universitas Muslim Indonesia (UMI), Makassar City. Indonesia

Email: anditenrisanna.arifuddin@umi.ac.id

\begin{abstract}
Background and Objectives: During pandemic Covid-19 period, all learning activities for clerkship medical students were carried out using the online method including case based learning, references review, case reports, journal reviews, and patient case discussions in the form of portfolios. This study analyzed the differences in learning online methods during the Covid-19 pandemic and offline methods before the Covid-19 pandemic in achieving cognitive competency for the clerkship students of doctor profession study program of faculty of medicine UMI.

Method: The study was conducted on all clerkship students of doctor profession study program, Faculty of Medicine, Muslim University of Indonesia, who participated in the clinical clerkship for the period 2019-2020. This study used a total sampling method with a total of 3,013 samples with Quantitative research with PreExperimental Design. The data compared and analyzed the pretest average scores which were carried out before clinical rotation and post test average score which were carried out after completing the clinical rotation in each department. Data were analyzed using the Wilcoxon Test.

Results: The average pre test value is 37,39\% and 38,28\% before and during pandemic Covid-19 using online method, respectively while posttest average value is 79,28\% and 79,17\% before and during pandemic Covid-19 using online method, respectively. The difference is not statistically significant.

Conclusions and Suggestions: Achievement of doctor profession program students cognitive competence by learning online methods during the Covid-19 pandemic are a good solution in achieving student cognitive competence during the Covid-19 pandemic and can be combined in the period after the Covid-19 pandemic in the form of blended learning.
\end{abstract}

Keywords: Online method, Pre test, Post test, Pandemic Covid-19.

\section{INTRODUCTION}

\subsection{Doctor Profession Program}

Clerkship students of doctor profession study program is a professional stage in medical education which is carried out in the form of clinical learning and community learning with various levels and forms of health services that aim to meet student competencies before being declared a doctor. This Doctor Profession Program is an advanced program for students who have completed an undergraduate medical education program. In addition, medical profession education students must complete administrative obligations in the professional stage of the Undergraduate Medical Education Program $[1,2]$.

\subsection{Competence of Indonesian Doctors}

The student learning process at the professional stage is based on the competencies as stated in the Indonesian Doctor Competency Standards set by the KKI. Professional Education aims to provide 
opportunities for students to understand theory, train clinical skills and clinical procedures and train 7 areas of doctor competence. With the objectives and systems that have been implemented, it is hoped that professional education graduates can use their knowledge and skills in the future society ethically, be able to manage individual and community health both for promotive, preventive and curative actions, and can improve knowledge for themselves and society $[1,3]$.

Medical Professional Education is directed at the results of graduates who have mastered the ability to design and analyze and have the skills to apply science, technology and the art of primary care medical profession learning, which is based on the analytical skills obtained from the Undergraduate Medical Program [2,3].

In the Republic of Indonesia Law Number 29 of 2004 concerning Medical Practice Article 26 has outlined the need for a medical professional education standard. This professional standard was ratified as the Standar Kompetensi Dokter Indonesia (SKDI) and Standar Pendidikan Profesi Dokter $(S P P D)$ in 2006 and was updated in 2012. In line with the message in the law, the Indonesian Doctors Competency Test has been started since 2007. for the cooperation of the Association of Indonesian Medical Education Institutions and the Indonesian College of Doctors [1,4].

In 2013, Law Number 20 of 2013 concerning Medical Education was issued. Article 36 of this Law mandates that to complete the medical profession program. Students must pass a national competency test before taking the oath as a Doctor. Students who pass the competency test get a professional certificate issued by the college $[4,5]$.

\subsection{The COVID-19 pandemic}

The coronavirus disease 2019 (COVID-19) pandemic has impacted all aspects of our lives, including education and the economy, as we know it. Governments have issued stay-at-home directives, and as a result, colleges and universities have been shut down across the world. Hence, online classes have become a key component in the continuity of education $[6,7]$.

\subsection{Online Learning}

Online lectures are a system that is implemented in the implementation of education at the university level, namely the system used by teachers and students. This online lecture system was put in place to reduce the spread. "Online learning is learning that utilizes technology as an intermediary medium for teaching and learning participants which can be done not face to face between the teacher and the instructor who usually uses computer media or gadgets based on internet networks, which means that it has flexible characteristics and is easy to do by anyone, anywhere and anytime " [7,8].

In the implementation of online lectures using a medium by utilizing internet access in its implementation. There are various types of media used in online lectures, some are in the form of elearning and some are in the form of applications to meet face to face online, for example, such as zoom, google meet and other media, of course these media are very helpful and support in the implementation of online lectures $[6,7]$.

\subsection{Online Learning Faculty of Medicine \\ Universitas Muslim Indonesia (UMI)}

Based on the decree of the Minister of Education of the Republic of Indonesia and the policies of the Indonesian Muslim University Management that during the Covid-19 pandemic all learning activities were carried out using the online method. This regulation is then implemented in several clinical clerkship activities including case based learning, 
reading references, case reports, journal reviews, and patient case discussions in the form of portfolios $[2,9]$.

Written test, to assess cognitive abilities, is given at the beginning of the clinical rotation as a pre-test, which aims to find out prior knowledge which is a test that is carried out before starting the clinical clerkship in the part to be undertaken and the post test is a test that is carried out in the second week of the cycle, and will be given the opportunity to repeat as many as 3 times if the Medical Professional Education Student has not graduated with a Passing Limit of 70 , and will be given $1 \mathrm{x}$ opportunity to improve grades if the Medical Professional Education Student passes This Posttest Exam is considered important to test the level of knowledge of the Medical Professional Education Student of the material that will and has been delivered in their respective sections. During the Covid 19 pandemic, this exam was carried out online, examination monitoring was also carried out online by each section facilitator.

This research needs to be carried out to analyze the effectiveness and differences of learning online methods during the COVID-19 pandemic and offline methods before the COVID-19 pandemic in achieving cognitive competence in medical profession education students, Faculty of Medicine, Muslim University of Indonesia.

\section{METHOD}

The study was conducted on all Medical profession education students, Faculty of Medicine, Muslim University of Indonesia, who participated in the clinical partnership for the period 2019-2020. This study used a total sampling method with a total of 3,013 samples.

Quantitative research with Pre-Experimental Design. The data analyzed were the pretest scores which were carried out before the medical profession education students carried out clinical clerkship and the post-test scores which were carried out after completing the clinical secretariat in all clinical sections of the Faculty of Medicine, Muslim University of Indonesia.

This study will use the Wilcoxon Test to find out the difference in the average pretest and posttest scores of medical profession education students between 2019 before the Covid-19 pandemic and 2020 during the Covid-19 pandemic.

\section{RESULT}

Medical profession education students, Faculty of Medicine, Muslim University of Indonesia, who participated in the clinical partnership for the period 2019-2020 with a total sample of 3013 samples.

Table 1.The comparison of the Clerkship students of doctor profession study program pretest and posttest values between 2019 Before the Covid19 pandemic in 2019, the number of Clerkship students of doctor profession study program was 2,013 people with an average pretest value of 37.39 with a standard deviation of 13.13 while the average posttest score was 79.17 with a standard deviation of 8.56. Meanwhile, during the Covid-19 pandemic in 2020, there were 1,000 Clerkship students of doctor profession study program with an average pretest value of 38.28 with a standard deviation of 13.81 while the average posttest score was 79.28 with a standard deviation of 9.89. The value of Asymptotic Significance (2-sided) in the Wilcoxon Test between the 2019 and 2020 pretest and posttest values is the same, namely 0,000 .

Table 1. Wilcoxon test results compare the Medical profession education students pretest and posttest values between 2019 and 2020

\begin{tabular}{cc|c|c|c|c}
\multirow{2}{*}{ Year } & \multicolumn{2}{c}{ Pre } & \multicolumn{2}{c}{ Post } & P Score \\
\cline { 2 - 6 } & mean & SD & mean & SD & \\
\hline $\mathbf{2 0 1 9}$ & 37.39 & 13.13 & 79.17 & 8.56 & $0.000^{*}$ \\
\hline
\end{tabular}


2020

\begin{tabular}{|l|l|l|l|l|}
\hline 38.28 & 13.81 & 79.28 & 9.89 & $0.000 *$ \\
\hline
\end{tabular}

Table 2. Comparison of the Medical profession education students pretest and posttest values for each part of 2019 before the Covid-19 pandemic. It was found that the average pretest score on all department are the lowest score was 31.97 with a standard deviation of 10.93 in Eye department and the highest score was 45.37 with a standard deviation of 16.62 in the Radiology department, while for the posttest the lowest score was 74.99 with a standard deviation of 9.11 in the obstetric and gynecologic department and the highest score was 87.50 with a standard deviation of 6.66 in Radiologic department. The value of Asymptotic Significance (2-sided) in the Wilcoxon Test between the pretest and posttest values for all parts of 2019 is the same, namely 0.000 .

Table 2. Wilcoxon test results comparison of values Medical profession education students pretest and posttest test per department in 2019

\begin{tabular}{|c|c|c|c|c|c|}
\hline \multirow{2}{*}{$\begin{array}{c}\text { Departme } \\
\text { nt }\end{array}$} & \multicolumn{2}{|c|}{ Pre } & \multicolumn{2}{|c|}{ Post } & \multirow[t]{2}{*}{ P Scor } \\
\hline & mean & SD & $\begin{array}{c}\text { mea } \\
\mathrm{n}\end{array}$ & SD & \\
\hline Pediatric & 36.45 & 11.80 & $\begin{array}{c}81.2 \\
4\end{array}$ & 6.05 & $\begin{array}{c}0.000 \\
*\end{array}$ \\
\hline $\begin{array}{c}\text { Anesthesi } \\
\mathbf{a}\end{array}$ & 43.84 & 12.54 & $\begin{array}{c}80.6 \\
1\end{array}$ & 8.29 & $\begin{array}{c}0.000 \\
*\end{array}$ \\
\hline Surgery & 34.79 & 10.75 & $\begin{array}{c}78.7 \\
4\end{array}$ & 8.54 & $\begin{array}{c}0.000 \\
*\end{array}$ \\
\hline Forensic & 37.15 & 10.43 & $\begin{array}{c}76.4 \\
7\end{array}$ & 5.44 & $\begin{array}{c}0.000 \\
*\end{array}$ \\
\hline $\begin{array}{l}\text { Public } \\
\text { Health }\end{array}$ & 34.07 & 12.52 & $\begin{array}{c}81.7 \\
1\end{array}$ & 7.68 & $\begin{array}{c}0.000 \\
*\end{array}$ \\
\hline $\begin{array}{l}\text { Internal } \\
\text { Medicine }\end{array}$ & 39.25 & 13.08 & $\begin{array}{c}78.0 \\
4\end{array}$ & 10.49 & $\begin{array}{l}0.000 \\
*\end{array}$ \\
\hline $\begin{array}{c}\text { Psychiatri } \\
\text { c }\end{array}$ & 41.01 & 11.67 & $\begin{array}{c}78.2 \\
6\end{array}$ & 7.55 & $\begin{array}{l}0.000 \\
*\end{array}$ \\
\hline $\begin{array}{c}\text { Cardiologi } \\
\text { c }\end{array}$ & 34.44 & 14.44 & $\begin{array}{c}75.7 \\
6\end{array}$ & 8.96 & $\begin{array}{l}0.000 \\
*\end{array}$ \\
\hline $\begin{array}{l}\text { Dermatolo } \\
\text { gic }\end{array}$ & 39.79 & 12.14 & $\begin{array}{c}79.0 \\
6\end{array}$ & 7.49 & $\begin{array}{l}0.000 \\
*\end{array}$ \\
\hline Eye & 31.97 & 10.93 & $\begin{array}{c}75.7 \\
7\end{array}$ & 8.71 & $\begin{array}{c}0.000 \\
*\end{array}$ \\
\hline $\begin{array}{c}\text { Neurologi } \\
\text { c }\end{array}$ & 37.75 & 12.04 & $\begin{array}{c}79.2 \\
1\end{array}$ & 8.37 & $\begin{array}{l}0.000 \\
*\end{array}$ \\
\hline
\end{tabular}

\begin{tabular}{|c|c|c|c|c|c|}
\hline Obgyn & 34.83 & 11.74 & $\begin{array}{c}74.9 \\
9\end{array}$ & 9.11 & 0.000 \\
$*$
\end{tabular}

Table 3. Comparison of the medical profession education students pretest and posttest scores for each part of 2020 during the Covid-19 pandemic. It was found that the average pretest score on all department are the lowest score was 30.70 with a standard deviation of 13.22 in Ear Nose Throat department and the highest score was 47.76 with a standard deviation of 19.26 in the Radiology department, while for the posttest the lowest score was 68.49 with a standard deviation of 11.55 in the obstetric and gynecologic department and the highest score was 87.87 with a standard deviation of 4.84 in Radiology department. The value of Asymptotic Significance (2-sided) in the Wilcoxon Test between the pretest and posttest values for all parts of 2019 is the same, namely 0.000 . The value of Asymptotic Significance (2-sided) on the Wilcoxon Test between the pretest and posttest values for all parts of 2020 is the same, namely 0.000 .

Table 3. Wilcoxon test results comparison of values medical profession education students pretest and posttest test per department in $\mathbf{2 0 2 0}$

\begin{tabular}{|c|c|c|c|c|c}
\multirow{2}{*}{ Department } & \multicolumn{2}{|c}{ Pre } & \multicolumn{2}{c}{ Post } & P Score \\
\cline { 2 - 5 } & mean & SD & mean & SD & \\
\hline Pediatric & 36.3 & 10.41 & 78.79 & 4.10 & $0.000^{*}$ \\
\hline $\begin{array}{c}\text { Anesthesi } \\
\text { a }\end{array}$ & $\begin{array}{c}43.6 \\
6\end{array}$ & 12.67 & 74.75 & 7.74 & $0.000^{*}$ \\
\hline Surgery & $\begin{array}{c}33.9 \\
4\end{array}$ & 10.96 & 85.65 & 7.96 & $0.000^{*}$ \\
\hline Forensic & $\begin{array}{c}35.7 \\
2\end{array}$ & 11.19 & 69.97 & 10.57 & $0.000^{*}$ \\
\hline $\begin{array}{c}\text { Public } \\
\text { Health }\end{array}$ & $\begin{array}{c}32.7 \\
4\end{array}$ & 11.73 & 79.02 & 5.50 & $0.000^{*}$ \\
\hline
\end{tabular}




\begin{tabular}{|c|c|c|c|c|c|}
\hline $\begin{array}{c}\text { Internal } \\
\text { Medicine }\end{array}$ & $\begin{array}{c}37.9 \\
0\end{array}$ & 10.50 & 82.83 & 6.56 & $0.000^{*}$ \\
\hline $\begin{array}{c}\text { Psychiatri } \\
\text { c }\end{array}$ & $\begin{array}{c}43.0 \\
8\end{array}$ & 13.97 & 81.63 & 6.98 & $0.000^{*}$ \\
\hline $\begin{array}{c}\text { Cardiologi } \\
\text { c }\end{array}$ & $\begin{array}{c}35.9 \\
7\end{array}$ & 16.48 & 84.21 & 8.37 & $0.000^{*}$ \\
\hline $\begin{array}{c}\text { Dermatolo } \\
\text { gic }\end{array}$ & $\begin{array}{c}44.9 \\
5\end{array}$ & 13.84 & 73.42 & 8.58 & $0.000^{*}$ \\
\hline Eye & $\begin{array}{c}31.7 \\
7\end{array}$ & 9.91 & 75.76 & 11.63 & $0.000^{*}$ \\
\hline & & & & & \\
\hline
\end{tabular}

\section{DISCUSSION}

The coronavirus disease 2019 (COVID-19) pandemic has impacted all aspects of our lives, including education and the economy, as we know it. Governments have issued stay-at-home directives, and as a result, colleges and universities have been shut down across the world.. Transitioning from face-to-face to online teaching can be challenging but is also rewarding. It is challenging to create a sense of social presence so that the online student feels a part of the learning community [10]. Some of the frequently mentioned advantages of online teaching are that it is convenient, efficient, challenging and can be fun and rewarding. Online instructors can teach from anywhere in the world as long as they have an internet connection. There is no class time missed due to illness, educational conferences, public holidays or even natural disasters. In addition to convenience, the online environment also offers excitement as well as new challenges for both learners and the instructor [7].

The method used is a literature review study which is an activity of looking for references related to the method of reading, taking notes, collecting data, and processing research materials from journals, reviewing journals, books, articles and the internet which are used to find and collect data. Research from primary data sources, namely from the results of an observation, and from secondary

\begin{tabular}{|c|c|c|c|c|c|}
\hline $\begin{array}{c}\text { Neurologi } \\
\text { c } \\
\text { Obgyn }\end{array}$ & $\begin{array}{c}39.6 \\
3\end{array}$ & 12.52 & 84.23 & 7.58 & $0.000^{*}$ \\
\hline $\begin{array}{c}\text { Orthopedi } \\
\text { c }\end{array}$ & $\begin{array}{c}40.3 \\
0\end{array}$ & 11.04 & 68.49 & 11.55 & $0.000^{*}$ \\
\hline Radiology & $\begin{array}{c}47.7 \\
6\end{array}$ & 19.26 & 80.68 & 4.56 & $0.000^{*}$ \\
\hline ENT & $\begin{array}{c}30.7 \\
0\end{array}$ & 13.22 & 80.63 & 4.84 & $0.000^{*}$ \\
\hline
\end{tabular}

data sources obtained from journal documents, articles and the internet. From this literature study method has the final result, which is to determine the impact of online lectures on student abilities. In the implementation of online lectures using a medium by utilizing internet access in its implementation. There are various types of media used in online lectures for example, such as zoom, google meet and other media, of course these media are very helpful and support in the implementation of online lectures. This regulation is then implemented in several clinical clerkship activities including case based learning, reading references, case reports, journal reviews, and patient case discussions in the form of portfolios especially for clerkship students of doctor profession study program faculty of medicine, Muslim University of Indonesia [6,7,10].

Clerkship students of doctor profession study program faculty of medicine as a student who follows the professional stage in medical education are required to be able to master 7 competency areas consisting of noble professionalism, introspection and self-development, effective communication, and supported by pillars in the form of information management, scientific foundation of medical science, clinical skills, and management of health problems. Students must pass a national competency test before taking the oath as a Doctor. Students who pass the competency test get a professional certificate issued by the college[1,2,4].

These circumstances makes the faculty of medicine, Muslim University of Indonesia apply 
pretest and posttest in each department in addition to improving student cognitive also to prepare students for Indonesian medical competency exams, and the covid-19 pandemic situation does not prevent students from achieving the same cognitive competencies as before the covid-19 pandemic.

\section{CONCLUSIONS AND SUGGESTIONS}

The effectiveness of online learning methods during the Covid-19 pandemic was as effective as learning before the Covid-19 pandemic in achieving cognitive competencies for clerkship students of doctor profession study program Faculty of Medicine, Muslim University of Indonesia. It is hoped that in the future the online secretariat method of Faculty of Medicine, Muslim University of Indonesia clinic will continue to be implemented during the Covid-19 pandemic.

\section{REFERENCES}

[1], Konsil Kedokteran Indonesia, Standar Kompetensi Dokter Indonesia, KKI, Jakarta 2012

[2]. Pamjaki A. Undang - Undang Republik Indonesia Nomer 20 Tahun 2013 tentang Pendidikan Kedokteran. Published online 2007. http://www.pamjaki.org/pamjaki35/files/download/regulasi/UU/UU-2013-20$\underline{\text { Pendidikan Kedokteran.pdf }}$

[3]. Ristekdikti P. Peraturan Menteri Riset, Teknologi, Dan Pendidikan Tinggi Republik Indonesia Nomor 18 Tahun 2015 Tentang Tata Cara Pelaksanaan Uji Kompetensi Mahasiswa Program Profesi Dokter Atau Dokter Gigi. Published online 2015.

[4]. Menteri Pendidikan. (2020). Surat Edaran Nomor 3 Tahun 2020 Tentang Pelaksanaan Pendidikan dalam Masa Darurat CoronaVirus (COVID-19)

[5]. Kedokteran AP, Pendidikan K, Fk J. Kebijakan Kemdikbud: Direktur Jenderal Pendidikan Tinggi Potret Pendidikan Kedokteran Indonesia Tahun 2020. Published online 2020.
Achievement of doctor profession program students cognitive competence by learning online methods during the Covid-19 pandemic are a good solution in achieving student cognitive competence during the Covid-19 pandemic and can be combined in the period after the Covid-19 pandemic in the form of blended learning.

\section{AUTHORS' CONTRIBUTIONS}

All authors contributed to study planning, and data collection and interpretation, and reviewed and approved the final version of this manuscript.

\section{ACKNOWLEDGMENTS}

Thanks are conveyed to the entire team of the Profession Doctor Study Program, Faculty of Medicine, Universitas Muslim Indonesia who have helped during this research.

[6]. Harapani Aprilia. (2020). PENGARUH KULIAH DARING SAAT PANDEMI COVID-19 TERHADAP KEMAMPUAN MAHASISWA. Program Studi Psikologi Fakultas Kedokteran Universitas Lambung Mangkurat. (Online) Tersedia https://www.google.com/url?sa=t\&rct=j\&q= $\underline{\& e s r c}=\mathrm{s} \&$ source $=$ web $\& \mathrm{~cd}=\& \mathrm{cad}=\mathrm{rja} \& u a c t=$ 8\&ved=2ahUKEwi0nLzW34LvAhXY7XMB HWIjC1EQFjABegQIARAD\&url=https\%3A \%2F\%2Fpsyarxiv.com\%2Ft4x29\%2Fdownlo ad\&usg=AOvVaw203Rs4zgYAJXmEWKtm5EM. (Diakses : 25 Januari 2021

[7]. Rajab M H, Gazal A M, Alkattan K (2020) Challenges to Online Medical Education During the COVID-19 Pandemic. Cureus 12(7): e8966. (Online) Tersedia https://www.ncbi.nlm.nih.gov/pmc/articles/P MC7398724/pdf/cureus-001200000008966.pdf. (Diakses : 25 Januari 2021

[8]. Arizona, Kurniawan. et.all. (2020). Pembelajaran Online Berbasis Proyek Salah Satu Solusi Kegiatan Belajar Mengajar di Tengah Pandemi Covid-19 . Jurnal Ilmiah Profesi Pendidikan. Volume 5 No 1 Mei 2020. (Online) Tersedia https://jipp.unram.ac.id/index.php/jipp/article/ download/111/99. (Diakses : 25 Januari 2021)

[9]. Abidin Zainal. et all. (2020). PEMBELAJARAN ONLINE BERBASIS 
PROYEK SALAH SATU SOLUSI KEGIATAN BELAJAR MENGAJAR DI TENGAH PANDEMI COVID-19. Jurnal Ilmiah Profesi Pendidikan. Volume 5 No 1 Mei 2020. (Online) Tersedia. (Diakses : 25
Januari 2021)

[10]. Esani M. (2010) Moving from face-to-face to online teaching . Clin Lab Sci., 23:187-190. 10.29074/ascls.23.3.187 